\title{
PENGARUH EARNING PER SHARE (EPS) DAN DIVIDEN PER SHARE (DPS) TERHADAP HARGA SAHAM PT WIJAYA KARYA (PERSERO) TBK
}

\author{
Reza Oktavian ${ }^{1)}$ \\ 1) dosen universitas pamulang, email : rezadaswar@yahoo.com
}

\section{ARTICLES}

JURNAL SEKURITAS

(Saham, Ekonomi, Keuangan dan Investasi )

Vol.2, No.2, Januari 2019 Halaman : $156-171$

(c) LPPM \& Prodi Manajemen UNVERSITAS PAMULANG

ISSN (online) : 2581-2777

ISSN (print) : :2581-2696

\section{Keyword :}

Earning Per Share (EPS), Dividen Per Share (DPS), Harga Saham.

JEL. classification :

C33, G21, G34, N25

\section{Contact Author :}

PRODI MANAJEMEN UNPAM

JL.Surya Kencana No.1 Pamulang

Tangerang Selatan - Banten

Telp. (021) 7412566, Fax (021) 7412491 Email :

jurnalfinance.unpam@gmail.com
Tujuan dari penelitian ini adalah Mengetahuin nilai Earning Per Share (EPS), Dividend Per Share (DPS) dan Harga Saham pada PT Wijaya Karya (Persero) Tbk guna mengetahui pengaruh Earning Per Share (EPS) dan Dividend Per Share (DPS) baik secara parsial maupun simultan terhadap harga saham WIKA pada periode 2010-2014.Metode penelitian mengunakan pendekatan deskriptif asosiatif serta analisis data menggunakan analisis regresi linier berganda dan pengujian asumsi klasik yang meliputi : Uji Normalitas, koefisien korelasi linier berganda dan parsial serta koefisien determinasi (Adj R.Square). Berdasarkan hasil analisis data, variabel EPS tertinggi PT. WIKA terjadi pada tahun 2014 yaitu sebesar 119.71 dan tahun terendah terjadi pada tahun 2010 yaitu sebesar 51.86. DPS pada tahun 2010-2013 mengalami peningkatan, dimulai pada tahun 2010 sebesar 15.55 , tahun 2011 sebesar 23.33, tahun 2012 sebesar 25.88, dan pada tahun 2013 sebesar 30.50. Tetapi pada tahun 2014 mengalami penurunan sebesar 23.94. DPS menunjukan trend fluktuatif. Uji signifikansi (Uji T) pada variabel EPS diperoleh ${ }_{\text {hitumg }}(21,435)>$ $t_{\text {tabel }}(4,303)$ sehingga jatuh pada daerah penolakan $H_{o}\left(H_{\sigma}\right.$ ditolak, $H_{1}$ diterima) dapat dilihat pula besar angka signifikansi yaitu 0,002 yang berarti angka ini lebih kecil dari tingkat signifikansi $(0,002<0,05)$, maka dapat ditarik kesimpulan bahwa perubahan EPS secara parsial berpengaruh signifikansi terhadap perubahan harga saham. Dengan melakukan perbandingan pada variabel DPS yaitu $t_{\text {hitung }}(-9,842)<t_{\text {tabel }}(4,303)$ sehingga dapat dilihat pula besar angka signifikansi sebesar 0,010 yang berarti angka ini lebih besar dari tingkat signifikansi $(0,010>$ $0,05)$, maka dapat ditarik kesimpulan bahwa perubahan DPS secara parsial tidak berpengaruh signifikan terhadap perubahan harga saham. Hasil uji signikansi (Uji F) dengan kondisi ini dimana $F_{\text {hitumg }}$ lebih besar dari pada $F_{\text {tabel }}(251,851>9,55)$ dan nilai signifikansi lebih kecil dari $\alpha=0,005(0,004<0,05)$, maka dapat diambil kesimpulan adalah $H_{o}$ ditolak dan $H_{1}$ diterima yang berarti variabel EPS dan DPS berpengaruh signifikan secara simultan terhadap harga saham. Koefisien Determinasi $R^{2}$ kondisi ini menunjukkan, seberapa besarnya pendapatan diterima oleh pemegang saham. jadi dapat disimpulkan bahwa EPS dan DPS berpengaruh sebesar 99,2\% terhadap Harga Saham, sedangkan $1,8 \%$ dipengaruhi oleh variabel lain yang tidak diketahui di dalam penelitian ini. 


\section{A. Pendahuluan}

Pasar modal merupakan pasar untuk berbagi instrumen keuangan yang bisa diperjualbelikan, baik yang diterbitkan oleh perusahaan pemerintah maupun perusahaan swasta. Pasar modal menjadi sarana perusahaan untuk memenuhi kebutuhan dana dengan menjual saham atau obligasi. Untuk menarik para investor, maka pasar modal harus bersifat efisien dan likuid. Pasar modal dikatakan efisien jika penjual dan pembeli surat berharga dapat bertransaksi dengan cepat. Sedangkan pasar modal dikatakan liquid jika harga dari sekuritas mencermikan nilai dari perusahaan secara akurat.

Pada umumnya tujuan investor melakukan investasi saham yaitu untuk mendapatkan capital gain. Capital gain yaitu selisih lebih harga saham pada saat menjual dan membeli saham. Harga saham dalam suatu bursa efek pada kenyataan memiliki tingkat ketidak stabilan sehingga para investor harus melakukan analisis agar kenaikan dan penurunan harga saham yang terjadi pada suatu bursa efek masih dalam batas-batas kewajaran. Nilai saham menggambarkan nilai perusahaan, sehingga nilai saham sangat dipengaruhi oleh prestasi dan kinerja perusahaan serta prospek perusahaan dalam meningkatkan nilai perusahaan di masa yang akan datang. Jika prestasi dan kinerja meningkat, maka investor akan menerima penghasilan dari saham yang dimiliki berupa dividen dan capital gain. Apabila perusahaan tersebut go public maka capital gain adalah selisih harga jual saham denga harga beli saham.

Dividen adalah laba yang diberikan emiten kepada para pemegang saham. Dari laba bersih perusahaan, sebagian dibagikan kepada pemegang saham dalam bentuk dividen, sebagian lagi disisihkan menjadi laba ditahan (retained earning). Laba ditahan merupakan salah satu sumber dana yang terpenting untuk membiayai pertumbuhan perusahaan. Perusahaan yang bisa memberikan dividen yang besar. Harga sahamnya juga akan meningkat. Sebaliknya perusahaan yang terus menerus tidak membagikan dividen, harga sahamnya akan menurun. Jika laba bersih perusahaan meningkat maka harga saham juga akan naik. (Taranika Intan, 2009). Adapun permasalahan yang dihadapi oleh investor pasar modal adalah adanya kesulitan untuk menentukan keputusan investasinya dan faktor apa yang menentukan harga saham di bursa. Para pemegang saham perusahaan dalam menanamkan investasinya senantiasa menginkan agar laba per lembar saham atau Earning Per Share (EPS) yang dimiliki meningkat. Dalam pasar modal terdapat beberapa kategori saham diantaranya adalah kategori saham manufaktur, food and beverages, real estate, property, tambang, konstruksi, perbankan dan sebagainya.

Kinerja keuangan PT Wijaya Karya (Persero) Tbk yang menghasilkan laba yang baik maka akan meningkatkan pula harga sahamnya. Fluktuasinya harga saham pada perusahaan konstruksi WIKA inilah yang menarik minat penulis guna menganalisa harga saham dan hubungan-hubungan yang mempengaruhinya. Baik hubungan antara Earning Per Share (EPS), Dividend Per Share (DPS), investor dan harga saham.

Menyangkut harga saham yang terkait dengan Earning Per Share (EPS) dan Dividend Per Share (DPS), beberapa penelitian yang dilakukan sebelumnya masih memberikan hasil yang beragam, seperti hasil penelitian yang dilakukan oleh Fica (2009) dari Universitas MDP (Multi Data Palembang) menyatakan bahwa Earning Per Share (EPS) mempunyai pengaruh 
yang signifikan terhadap harga saham. Sedangkan menurut penelitian yang dilakukan oleh Setyaningsih (2007) Earning Per Share (EPS) tidak berpengaruh terhadap harga saham.

Dari uraian di atas maka penulis tertarik untuk mencoba melakukan pembahasan dan penyusunan penelitian dengan judul "Pengaruh Earning Per Share (EPS) dan Dividen Per Share (DPS) Terhadap Harga Saham PT Wijaya Karya (Persero) Tbk".

\section{Rumusan Masalah}

Berdasarkan latar belakang masalah yang diuraikan, penulis merumuskan permasalahan sebagai berikut:

1. Bagaimana Pengaruh Earning Per Share (EPS) terhadap harga saham WIKA pada periode 2010-2014?

2. Bagaimana Pengaruh Dividend Per Share (DPS) terhadap harga saham WIKA pada periode 2010-2014?

3. Bagaimana Pengaruh Earning Per Share (EPS) dan Dividend Per Share (DPS) secara simultan terhadap harga saham pada WIKA periode 2010-2014?

\section{E. Tujuan Penelitian}

Berdasarkan latar belakang dan rumusan masalah yang telah diuraikan sebelumnya maka tujuan penelitian ini adalah:

a. Untuk mengetahui Pengaruh Earning Per Share (EPS) Pada WIKA periode 20102014 ?

b. Untuk mengetahui Pengaruh Dividend Per Share (DPS) Pada WIKA periode 20102014?

c. Untuk mengetahui Pengaruh Earning Per Share (EPS) dan Dividend Per Share (DPS) secara simultan terhadap harga saham pada WIKA periode 2010-2014?

\section{F. Kerangka Berpikir}

Gambar 1.1.

Kerangka Pemikiran

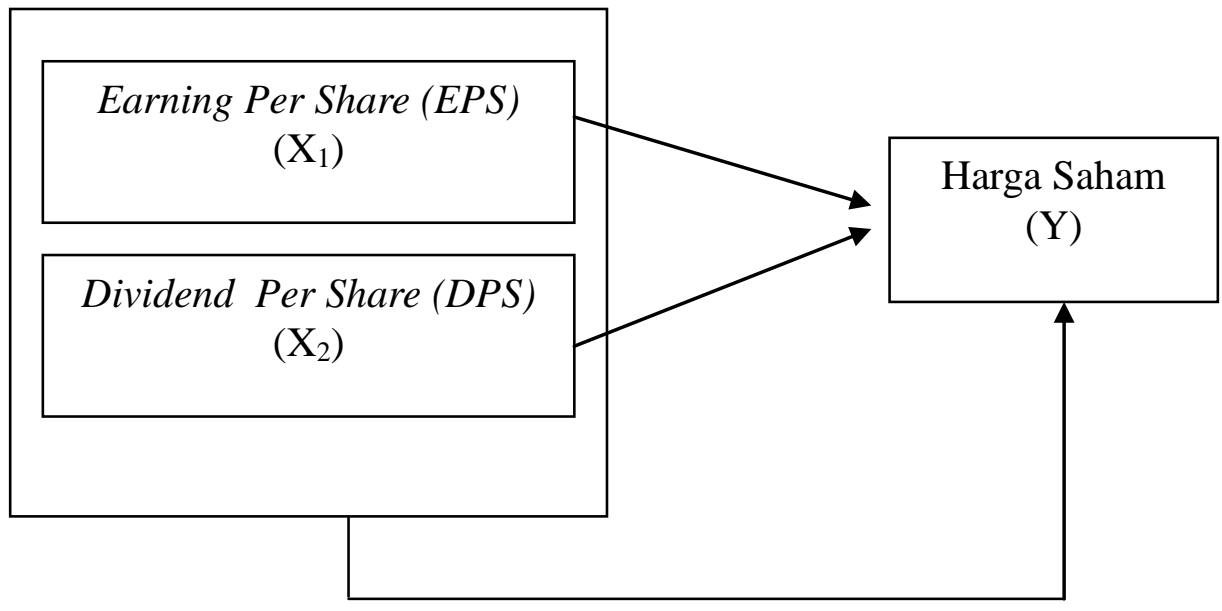




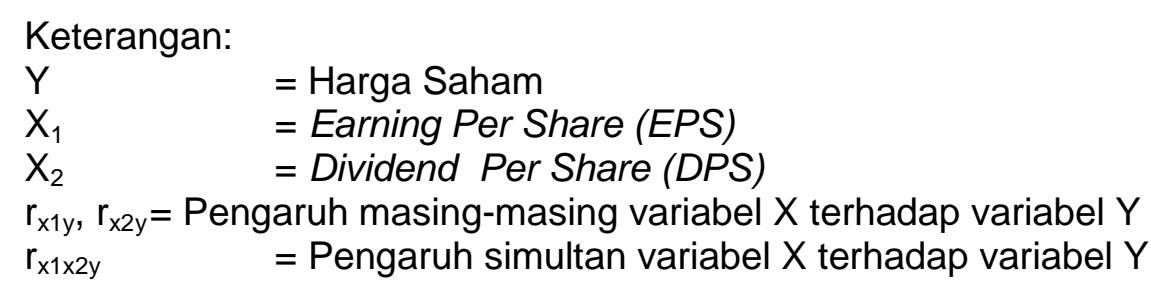

\section{G. Hipotesis}

Berdasarkan kerangka berfikir yang telah diuraikan di atas, maka hipotesis yang diajukan dalam penelitian ini:

$\mathrm{H}_{\mathrm{o}} \quad$ : Tidak Terdapat Pengaruh antara Earning Per Share (EPS) dan Dividend Per Share (DPS) terhadap Harga Saham WIKA periode 2010-2014.

$\mathrm{H}_{1} \quad$ : Terdapat Pengaruh secara parsial antara Earning Per Share (EPS) dan Dividend Per Share (DPS) terhadap Harga Saham WIKA periode 2010-2014.

$\mathrm{H}_{2}$ : Terdapat Pengaruh secara simultan antara Earning Per Share (EPS) dan Dividend Per Share (DPS) terhadap Harga Saham WIKA periode 2010-2014.

\section{TINJAUAN PUSTAKA}

\section{Saham}

Saham (stock atau share) dapat didefinisikan sebagai tanda penyertaan atau pemilikan seseorang atau badan dalam suatu perusahaan atau perseroan terbatas. Saham berwujud selembar kertas yang menerangkan bahwa pemilik kertas adalah pemilik perusahaan yang menerbitkan surat berharga tersebut. Porsi kepemilikan ditentukan oleh seberapa besar penyertaan yang ditanamkan di dalam perusahaan tersebut (Darmadji dan Fakhruddin, 2006). Saham menurut Jogiyanto (2000:8) adalah suatu bentuk sekuritas yang dikeluarkan perusahaan dimana terjadi transaksi penjualan hak dan kepemilikannya.

\section{Pasar Modal}

Menurut Rusdin (2008:1), pasar modal merupakan kegiatan yang berhubungan dengan penawaran umum dan perdagangan efek, perusahaan publik yang berkaitan dengan efek yang diterbitkannya, serta lembaga dan profesiyang berkaitan dengan efek. Pasar modal bertindak sebagai penghubung antara para investor dengan perusahaan ataupun institusi pemerintah melalui perdagangan instrumen keuangan jangka panjang seperti obligasi, saham dan lainnya.

Pasar modal (capital market) adalah lembaga keuangan bukan bank yang mempunyai kegiatan berupa penawaran dan perdagangan efek (Ade Arthesa \& Edia Handiman, 2006:215). Selain itu pasar modal juga merupakan lembaga profesi yang berkaitan dengan transaksi jual beli efek dan perusahaan publik yang berkaitan dengan efek.

Pasar modal (capital market) adalah lembaga keuangan yang menyediakan dana permodalan berjangka panjang yaitu lebih dari satu tahun (Murdifin Haming dan Salim Basalamah, 2010:353). Dalam Undang-Undang No. 8 Tahun 1995 tentang Pasar Modal pada pasal 1 ayat 13 disebutkan bahwa Pasar Modal adalah kegiatan yang bersangkutan dengan penawaran umum dan perdagangan efek, perusahaan publik yang berkaitan dengan efek yang diterbitkannya, serta lembaga dan profesi yang berkaitan dengan efek. Selanjutnya, dalam ayat 15 disebutkan bahwa penawaran umum adalah kegiatan penawaran efek yang dilakukan oleh emiten untuk menjual efek kepada masyarakat berdasarkan tata cara yang 
diatur dalam undang-undang ini dan peraturan pelaksanaannya.

Dalam pasal 1 ayat 4 disebutkan Bursa Efek adalah pihak yang menyelenggarakan dan menyediakan sistem dan/ atau sarana untuk mempertemukan penawaran jual dan beli efek pihak-pihak lain dengan tujuan memperdagangkan efek di antara mereka.

Seorang investor yang akan menanamkan investasi di pasar modal seringkali memusatkan perhatian pada kondisi keuangan perusahaan dalam melakukan analisinya. Kondisi keuangan perusahaan itu biasanya disajikan dalam bentuk laporan keuangan yang terdiri dari neraca dan laporan laba rugi. Sehingga dengan memahami laporan keuangan perusahaan tersebut dapat memudahkan investor dalam meramalkan prospek profitabilitasnya. Dari laporan keuangan tersebut, selanjutnya dapat dihitung laba per lembar saham yang akan di bagikan perusahaan. Pengertian laba per lembar saham menurut (Darmadji dan Fakhruddin, 2006: 195) adalah sebagai berikut: "Laba per lembar saham merupakan rasio yang menunjukan bagian laba untuk setiap saham". Kondisi ataupun prospek perusahaan merupakan salah satu faktor yang mempengaruhi harga saham yang dicerminkan oleh Earning Per Share (EPS) yang dimiliki perusahaan tersebut.

Sawidji Widoatmodjo (2005:102) mengatakan bahwa "Semakin tinggi laba per lembar saham Earning Per Share (EPS), maka semakin mahal harga suatu saham dan sebaliknya". Darmadji dan Fakhruddin (2006:195-196) mengatakan bahwa: "Semakin tinggi nilai laba per lembar saham Earning Per Share (EPS) tentu saja menyebabkan semakin besar laba sehingga mengakibatkan harga pasar saham naik karena permintaan dan penawaran meningkat".

Earning Per Share (EPS) adalah perbandingan jumlah Earning After Tax (EAT) dengan jumlah lembar saham perusahaan (Tandelilin, 2001:233). Semakin besar Earning Per Share (EPS) menunjukkan keuntungan perusahaan yang semakin besar Earning Per Share (EPS) menunjukkan keuntungan perusahaan yang semakin tinggi. Tingginya tingkat keuntungan perusahaan merupakan daya tarik bagi investor untuk memiliki saham perusahaan tersebut karena salah satu tujuan investor untuk memiliki saham perusahaan tersebut karena salah satu tujuan investor membeli saham adalah untuk mendapatkan keuntungan modal yang sebesar-besarnya.

Pernyataan tersebut diatas diperkuat oleh hasil penelitian Andri Rachman (2012) yang menghasilkan bahwa Earning Per Share (EPS) mempunyai pengaruh signifikan terhadap harga saham. Dari teori diatas dapat diketahui bahwa hubungan antara laba per lembar saham dengan harga pasar saham sangat erat. Dengan demikian dapat disimpulkan bahwa laba per lembar saham dapat mempengaruhi harga pasar saham.

Dividend Per Share (DPS) adalah sejumlah keuntungan yang akan dibagikan kepada pemegang saham. Dividend Per Share (DPS) dapat meningkatkan harga saham karena dividen yang stabil dan dapat diprediksi dianggap mempunyai risiko yang kecil (Sutrisno, 2003:305). Dividend Per Share (DPS) mencerminkan perusahaan mempunyai prospek yang baik dan akan menarik investor yang memanfaatkan dividen untuk keperluan konsumsi. Apabila Dividend Per Share (DPS )yang diterima naik tentu saja hal ini akan sangat mempengaruhi harga saham dipasar modal, karena naiknya Dividend Per Share (DPS) kemungkinan besar akan menarik investor untuk membeli saham perusahaan tersebut. Dengan banyaknya saham yang dibeli maka harga suatu saham perusahaan tersebut akan naik di pasar modal.

Pernyataan tersebut diatas diperkuat dari penelitian yang dilakukan oleh Intan, Taranika (2009) secara simultan variable dividen per share berpengaruh signifikan terhadap harga saham.

Dari teori diatas dapat diketahui bahwa hubungan antara dividen per lembar saham atau Dividend Per Share (DPS) dengan harga saham berhubungan. Dengan demikian disimpulkanlah bahwa dividen per lembar saham dapat mempengaruhi harga saham. 


\section{METODE PENELITIAN}

Jenis Riset dalam penelitian ini adalah penelitian deskriptif dengan menggunakan data kuantitatif (sekunder). Dilihat dari dimensi waktu yang digunakan, penelitian ini termasuk dalam kelompok data time series dengan menggunakan annual report 2010 - 2014 .Objek penelitian ini adalah corporate gorvernance (tata kelola perusahaan) dan corporate action berupa harga saham berdasarkan data yang dikeluarkan PT Wijaya Karya (persero) Tbk dengan menggunakan periode tahun 2010 - 2014.

Populasi yangh diambil dari penelitian ini yaitu perusahaan yang sudah go public yang terdapat pada Bursa Efek Indonesia (BEl). Perusahaan yang diambil adalah dari sektor konstruksi dari laporan keuangan tahun 2010-2014.

Dalam penelitian ini penarikan sample diambil secara purposive sampling, yaitu pengambilan sample non probability dimana metode ini menetapkan bahwa setiap elemen tidak mempunyai kesempatan yang sama untuk menjadi sample penelitian harus memenuhi syarat atau kriteria tertentu yang dapat digunakan sebagai sample untuk penelitian. Dalam Teknik ini sample harus memenuhi kriteria antara lain sebagai berikut :

a. Terdaftar di Bursa Efek Indonesia tahun 2010-2014 dan berupa sektor konstruksi.

b. Perusahaan tersebut secara periodik mengeluarkan laporan keuangan tiap tahunnya dan memiliki kelengkapan data selama periode pengamatan.

c. Memasyarakatkan sahamnya melalui Bursa Efek Indonesia.

Dari beberapa perusahaan konstruksi yang terdaftar di Bursa Efek Indonesia, peneliti hanya mengambil satu sampel perusahaan kontruksi saja untuk di teliti yaitu perusahaan PT Wijaya Karya (persero) Tbk.

\section{HASIL DAN PEMBAHASAN}

Pengelolahan data dilakukan dengan bantuan perangkat lunak (software) komputer dengan menggunakan Microsoft Excel dan SPSS (Statistikal Product and Service Solutions) 20.0 for Windows untuk mempercepat perolehan data hasil yang dapat menjelaskan variabel-variabel tang diteliti. Tabel deskriptif menunjukan semua variabel yang digunakan dalam model analisis regresi linier berganda, yaitu variabel $Y$ (Harga Saham), variabel EPS dan DPS sebagai variabel bebas.

\section{Earning Per Share pada WIKA}

EPS merupakan jumlah pendapatan atau keuntungan bersih dikurangi saham biasa untuk setiap lembar saham yang beredar saat menjalankan operasinya dalam suatu periode. Laba merupakan alat ukur utama kesuksesan suatu perusahaan, karena itu para pemodal seringkali memusatkan perhatian pada besarnya EPS dalam melakukan analisis saham. Semakin tinggi nilai EPS tentu saja menggembirakan pemegang saham karena semakin besar laba yang disediakan untuk pemegang saham.

Untuk mendapatkan data EPS dapat dilihat melalui laporan keuangan yaitu laporan laba dan rugi serta catatan atas laporan keuangan. Indikator yang digunakan untuk mengukur EPS dengan rumus :

EPS $=\frac{\text { Laba bersih setelah pajak }}{\text { Jumlah saham yang beredar }}$

Sumber : Eduardus Tandelilin (2010:365). 
Nilai EPS yang besar akan membuat ketertarikan investor besar terhadap saham suatu perusahaan yang mengakibatkan banyaknya permintaan saham tersebut, dampaknya adalah naiknya harga saham. Begitu pula sebaliknya, EPS yang rendah mengakibatkan kurangnya permintaan saham perusahaan tersebut juga akan menurunkan harga saham.

Dari hasil penelitian diperoleh gambaran EPS pada WIKA yang listing di Bursa Efek Indonesia sebagai berikut :

Tabel 4.1

EPS (Earning Per Share) pada PT. Wijaya Karya (Persero) Tbk Periode 2010-2014 (Dalam Jutaan Rupiah)

\begin{tabular}{|l|l|l|l|l|}
\hline No. & Tahun & Laba Bersih & $\begin{array}{l}\text { Jumlah } \\
\text { Saham yang } \\
\text { Beredar }\end{array}$ & EPS \\
\hline 1. & 2010 & 311.241 .250 & 6.001 .540 & 51.86 \\
\hline 2. & 2011 & 401.827 .929 & 6.027 .267 & 66.66 \\
\hline 3. & 2012 & 526.907 .280 & 6.105 .627 & 86.29 \\
\hline 4. & 2013 & 624.371 .679 & 6.139 .968 & 101.68 \\
\hline 5. & 2014 & 736.152 .495 & 6.149 .225 & 119.71 \\
\hline
\end{tabular}

Sumber: Data diolah

Untuk mengetahui lebih jelas serta memudahkan dalam membacanya mengenai EPS WIKA maka penulis menjabarkan dalam bentuk tulisan. Berdasarkan hasil perhitungan EPS pada WIKA yang terlihat pada Tabel 4.1 dijelaskan bahwa EPS WIKA selalu meningkat tiap tahunnya, dimulai dari tahun 2010 sampai dengan tahun 2014 tetapi pada tahun 2015 mengalami penurunan. Berdasarkan data diatas EPS tertinggi WIKA terjadi pada tahun 2014 yaitu sebesar 119.71 dan tahun terendah WIKA terjadi pada tahun 2010 yaitu sebesar 51.86. Laba bersih WIKA yang terus meningkat dimulai dari tahun 2010 sebesar 311.241 .250 naik menjadi 401.827.929 pada tahun 2011, dengan jumlah saham yang beredar pada tahun 2010 sebesar 6.001 .540 dan naik pada tahun 2011 sebesar 6.027.267 sehingga mengakibatkan kenaikan pada EPS dari 51.86 pada tahun 2010 menjadi 66.66 pada tahun 2011. Begitupun selanjutnya setiap tahunnya laba serta jumlah saham beredar terus meningkat sehingga $E P S$ pun meningkat sampai dengan tahun 2014.

Kondisi seperti ini disebabkan oleh jumlah saham yang beredar terus meningkat dan laba bersih selama tahun 2010 sampai dengan tahun 2014 juga terus meningkat.

2. Dividen Per Share (DPS) pada WIKA

DPS merupakan besarnya jumlah pendapatan per lembar saham yang akan didistribusikan pada para pemegang saham biasa, yang di dapat dengan cara membandingkan antara total dividen dengan jumlah saham yang beredar. Untuk mendapatkan data DPS dapat dilakukan dengan cara membagi total dividen dengan jumlah lembar saham yang beredar. Indikator yang digunakan untuk mengukur DPS adalah dengan rumus berikut :

$D P S=\frac{\text { Total Dividen }}{\text { Jumlah saham yang beredar }}$ 
Dividen yang stabil akan memberikan kesan kepada investor bahwa perusahaan mempunyai prospek yang baik di masa yang akan datang. Semakin besar DPS diharapkan harga saham semakin meningkat. Dari hasil penelitian diperoleh gambaran DPS pada WIKA yang listing di Bursa Efek Indonesia sebagai berikut:

Tabel 4.2

DPS (Dividen Per Share) Pada WIKA Periode 2010-2014 (Dalam Jutaan Rupiah)

\begin{tabular}{|l|l|l|l|l|}
\hline No. & Tahun & Total Dividen & $\begin{array}{l}\text { Jumlah Saham } \\
\text { yang Beredar }\end{array}$ & DPS \\
\hline 1. & 2010 & 93.372 .375 & 6.001 .540 & 15.55 \\
\hline 2. & 2011 & 140.639 .775 & 6.027 .267 & 23.33 \\
\hline 3. & 2012 & 158.072 .184 & 6.105 .627 & 25.88 \\
\hline 4. & 2013 & 187.311 .503 & 6.139 .968 & 30.50 \\
\hline 5. & 2014 & 147.230 .499 & 6.149 .225 & 23.94 \\
\hline
\end{tabular}

Sumber : Data diolah

Berdasarkan data pada Tabel 4.2 di atas dapat diketahui bahwa nilai DPS pada WIKA periode tahun 2010-2014 cenderung berfluktuatif. Pada tahun 2010 sampai 2013 terjadi kenaikan pembayaran DPS, sedangkan pada tahun 2014 mengalami penurunan pembayaran DPS.

Nilai DPS pada tahun 2010-2013 mengalami peningkatan, dimulai pada tahun 2010 sebesar 15.55, tahun 2011 sebesar 23.33, tahun 2012 sebesar 25.88, dan pada tahun 2013 sebesar 30.50. Tetapi pada tahun 2014 WIKA mengalami penurunan sebesar 23.94.

Berdasarkan data diatas, DPS menunjukan trend fluktuatif. Kondisi ini menunjukkan, seberapa besarnya pendapatan diterima oleh pemegang saham. DPS yang tinggi akan lebih diminati oleh para investor, karena akan memperoleh kepastian dari modal yang ditanamkan, yaitu hasil berupa dividen.

3. Harga Saham pada WIKA

Harga saham bertindak sebagai barometer dari kinerja bisnis yang dihasilkan oleh perusahaan dan akan selalu mengalami perubahan sesuai dengan keadaan pasar bursa. Menurut Agus Sartono (2003:41), harga saham adalam sama dengan harga pasar saham dan terbentuk melalui mekanisme permintaan dan penawaran di pasar dan menurutnya harga saham sama pengertiannya dengan nilai pasar.

Dalam pendekatan PER atau disebut juga pendekatan multiplier, PER menggambarkan rasio atau perbandingan atara harga saham terhadap earning perusahaan. Investor akan menghitung berapa kali (multiplier) nilai earning yang tercermin dalam harga suatu saham.

PER memberikan informasi berapa rupiah harga yang harus dibayar investor untuk memperoleh setiap Rp. 1 earning perusahaan.

Secara rumusnya untuk menghitung PER suatu saham adalah sebagai berikut :

$P E R=\frac{\text { Harga Saham }}{\text { Earning Per lembar Saham }}$ 
Peneliti memberikan gambaran tambahan tentang perubahan harga saham atau capital gain/ capital loss adalah pendapatan karena apresiasi harga sekuritas akibat dari harga penjualan lebih besar atau lebih kecil dari pada harga pembelian. Perubahan harga saham di peroleh dari data statistik harga saham yang dikeluarkan oleh BEI. Untuk dapat mengetahui besarnya perubahan saham menggunakan rumus:

Persentase Perubahan Harga $=\frac{P t-P t-^{1}}{P t-^{1}}$

Dimana :

Pt $\quad=$ Harga saham pada periode $\mathrm{t}$

$\mathrm{Pt}-1=$ Harga saham pada periode $\mathrm{t}^{1}{ }^{1}$

Tabel 4.3

Harga Saham (closing price) pada WIKA tahun 2010-2014 (Dalam Rupiah Penuh) beserta perubahannya

\begin{tabular}{|l|l|l|l|l|l|}
\hline No & Tahun & $\begin{array}{l}\text { Harga } \\
\text { Saham }\end{array}$ & EPS & Per & $\begin{array}{l}\text { Perubahan } \\
\text { Harga Saham }\end{array}$ \\
\hline 1 & 2010 & 680 & 51,86 & 13,11 & - \\
\hline 2 & 2011 & 610 & 66,66 & 9,15 & $-10 \%$ \\
\hline 3 & 2012 & 1480 & 86,29 & 17,15 & $143 \%$ \\
\hline 4 & 2013 & 1580 & 101,68 & 15,54 & $7 \%$ \\
\hline 5 & 2014 & 3680 & 119,82 & 30,74 & $133 \%$ \\
\hline
\end{tabular}

Data harga saham yang digunakan dalam penelitian ini menggunakan harga penutupan (closing price). Dari hasil penelitian diperoleh gambaran harga saham pada WIKA disajikan dalam tabel di atas :

Meningkatnya harga saham WIKA tahun 2011 sebesar 10\% merupakan dampak dari restrukturisasi yang terjadi tahun 2010 akibat laba yang rendah terjadi di tahun 2010 . Meningkatnya harga saham tahun 2012 sebesar 143\% merupakan dampak dari meningkatnya EPS di tahun 2006. Harga saham WIKA yang meningkat paling besar sebesar $143 \%$ pada tahun 2012, merupakan pemulihan dari krisis ekonomi dunia serta juga investor melihat grafik WIKA meningkat yang tidak mengalami dampak dari krisis ekonomi dunia. Peningkatan hara saham 2013 sebesar 3\% walaupun tidak terlalu besar ini membuktikan adanya kenaikan yang dipengaruhi oleh EPS serta kenaikan kembali yang signifikan di tahun 2014 sebesar 133\% yang disebabkan oleh kenaikan nilai laba bersih serta EPS yang meningkat.

Setelah melakukan pengolahan data maka penulis dapat menjelaskan mengenai variabelvariabel yang terdapat dalam model yang digunakan dalam penelitian ini, seperti terlihat dalam tabel dibawah ini.

Tabel 4.4

Tabel Deskripsi Data Variabel EPS dan DPS

Terhadap Harga Saham

Descriptive Statistics

\begin{tabular}{|l|l|l|l|l|l|}
\hline & $N$ & Minimum & Maximum & Mean & Std. Deviation \\
\hline Earning Per Share & 5 & 51,86 & 119,71 & 85,2400 & 27,01388 \\
Dividen Per Share & 5 & 15,55 & 30,50 & 23,8400 & 5,42013 \\
Harga Saham & 5 & 610,00 & 3680,00 & 1606,0000 & 1241,72461
\end{tabular}




\section{\begin{tabular}{|l|l|l|l|l|l|} 
Valid N (listwise) & 5 & & & &
\end{tabular}}

Sumber: Data diolah

Dari tabel 4.4 diatas dijelaskan bahwa variabel dependent yaitu harga saham dengan jumlah data sebanyak 5 memiliki nilai terkecil (minimum) sebesar 610,00 dan nilai terbesar (maximum) sebesar 3680,00 dan nilai rata-rata 1606,0000 dan standar deviasi 1241,72461. Earning Per Share dengan jumlah data sebanyak 5 memiliki nilai terkecil (minimum) sebesar 51,86 dan nilai terbesar (maximum) sebesar 119,71 serta nilai rata-rata EPS sebesar 85,2400 dan standar deviasi 27,01388. Dividen Per Share dengan jumlah data sebanyak 5 memiliki nilai terkecil (minimum) sebesar 15,55 dan nilai terbesar (maximum) sebesar 30,50 dan nilai rata-rata DPS sebesar 23,8400 dengan standar deviasi 5,42013.

\section{A. Pengujian Asumsi Klasik}

1. Normalitas Data

Uji normalitas data bertujuan untuk menguji apakah model regresi, variabel pengganggu atau residual memiliki distribusi normal. Ada dua cara untuk mendeteksi apakah residual berdistribusi normal atau tidak yaitu dengan analisis grafik dan uji statistik (Ghozali, 2005: 110112).

a) Analisis Grafik

Salah satu cara termudah untuk melihat normalitas residual adalah dengan melihat grafik histogram yang membandingkan antara data observasi dengan distribusi yang mendeteksi distribusi normal. Namun demikian hanya dengan melihat histogram hal ini dapat menyesatkan khususnya untuk jumlah sampel kecil. Metode yang lebih handal adalah dengan melihat normal probability plot, yaitu deteksi dengan melihat penyebaran data (titik) pada sumbu diagonal dari grafik.

\section{Gambar 4.1}

\section{Normal Probability Plot}

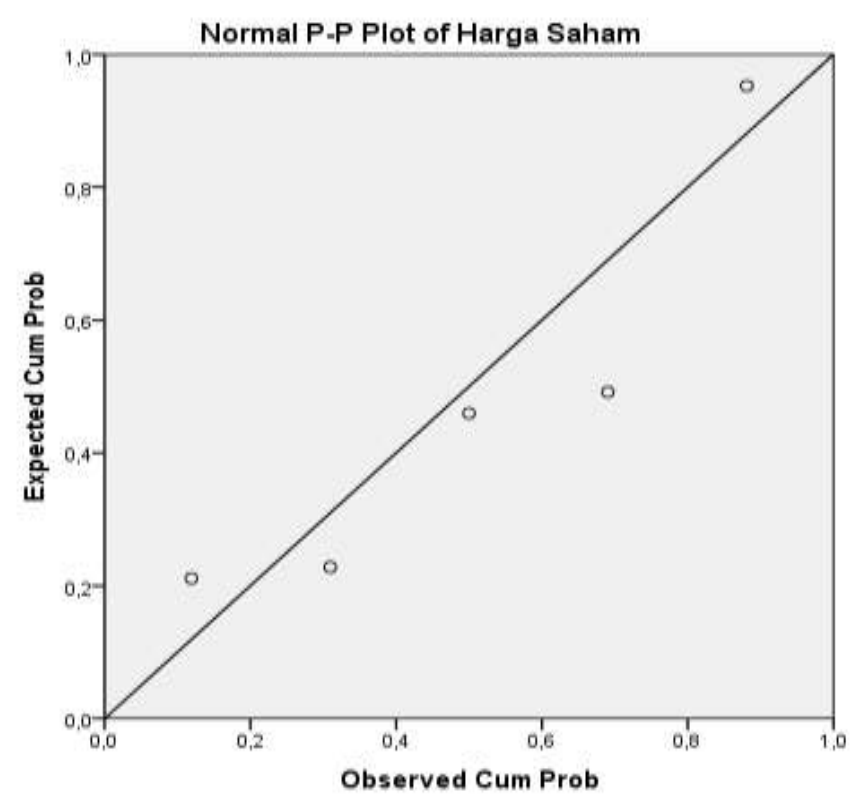


Dari hasil normal probability plot di atas dapat dilihat bahwa titik-titik plot (data) sedikit melebar dari garis diagonal atau menyebar disekitar garis diagonal serta mengikuti arah garis diagonalnya. Hal seperti ini dapat ditarik kesimpulan bahwa data tidak terdistribusi normal atau tidak memenuhi asumsi klasik normalitas.

b) Analisis Statistik

Uji normalitas dengan grafik dapat menyesatkan kalau tidak hati-hati secara visual kelihatan normal, padahal secara statistik bisa sebaliknya. Uji statistik dapat digunakan untuk menguji normal residual yaitu dengan uji statistik nonparametrik Kolmogorov-Smirnov (K-S). Dengan menggunakan alat bantu (software) SPSS versi 20.0 maka dihasilkan tabel sebagai berikut:

Dari hasil uji one-sample Kolmogorov-Smirnov dibawah diperoleh nilai Asymp. Sig. (2-tailed) sebesar 0,998. Artinya bahwa nilai tersebut 0,998 >0,05, maka dapat disimpulkan bahwa data berdistribusi normal.

Tabel 4.5

Uji Normalitas dengan Kolmogorov-Smirnov One-Sample Kolmogorov-Smirnov Test

\begin{tabular}{|ll|r|}
\hline & & \multicolumn{1}{|c|}{$\begin{array}{c}\text { Unstandardized } \\
\text { Residual }\end{array}$} \\
\hline N & Mean & 5 \\
Normal Parameters & Std. &, 0000000 \\
& Deviation & 78,08954992 \\
Most Extreme & Absolute &, 176 \\
Differences & Positive &, 176 \\
Kolmogorov-Smirnov Z & Negative &,- 173 \\
Asymp. Sig. (2-tailed) & &, 394 \\
\hline
\end{tabular}

Sumber: Data diolah

a. Test distribution is Normal.

b. Calculated from data.

\section{B. Analisis Regresi Linier Berganda}

Analisis regresi ini digunakan untuk mengetahui seberapa besar pengaruh variabel independen terhadap variabel dependen yaitu EPS dan DPS terhadap harga saham WIKA. Persamaan regresi linier yang digunakan adalah :

$$
Y=a+b_{1} x_{1}+b_{2} x_{2}
$$

Adapun perhitungan regresi linier berganda dibantu dengan menggunakan SPSS 20.0 for Windows dari data yang telah dianalisis adalah sebagai berikut:

Tabel 4.6

Hasil Analisis Regresi

Coefficients $^{\mathrm{a}}$

\begin{tabular}{|l|c|c|c|c|}
\hline Model & $\begin{array}{c}\text { Unstandardized } \\
\text { Coefficients }\end{array}$ & $\begin{array}{c}\text { Standardized } \\
\text { Coefficients }\end{array}$ & $\mathrm{t}$ & Sig. \\
\hline
\end{tabular}




\begin{tabular}{|l|r|r|r|r|r|}
\hline & \multicolumn{1}{|c|}{$\mathrm{B}$} & \multicolumn{1}{|c|}{ Std. Error } & \multicolumn{1}{|c|}{ Beta } & & \\
\hline (Constant) & $-239,704$ & 248,074 & &,- 966 &, 436 \\
Earning Per & 60,152 & 2,806 & 1,309 & 21,435 &, 002 \\
$1 \begin{array}{l}\text { Share } \\
\text { Dividen Per } \\
\text { Share }\end{array}$ & $-137,653$ & 13,986 &,- 601 & $-9,842$ &, 010 \\
\hline
\end{tabular}

Sumber: Data dioleh dengan SPSS 20.0

Dari tabel coefficient diatas maka diperoleh persamaan regresi sebagai berikut:

Persamaan regresi linier berganda diatas mempunyai interpretasi sebagai berikut:

1. Konstanta (a) sebesar -239,704 menunjukkan bahwa jika perubahan variabel EPS dan $D P S$ tidak konstan atau bernilai nol (EPS dan DPS $=0)$ maka nilai harga sahamnya adalah $-239,704$.

2. Variabel EPS sebesar 60,152 dan bertanda positif, hal ini berarti bahwa setiap perubahan 1 satuan pada pada perubahan EPS dengan asumsi variabel lainnya tidal tetap, maka perubahan harga sahamnya akan mengalami perubahan sebesar 60,152 dengan arah yang berbeda.

3. Variabel DPS sebesar $-137,653$ dan bertanda negatif, hal ini berarti bahwa setiap perubahan 1 satuan pada perubahan DPS dengan asumsi variabel lainnya tidak tetap, maka perubahan harga sahamnya akan mengalami perubahan sebesar $-137,653$ dengan arah berbeda.

\section{Analisis Kolerasi}

1. Koefisien Korelasi Linier Berganda

Koefisien korelasi ini menunjukkan kekuatan hubungan antara semua variabel bebas dan variabel terikat yang berfungsi untuk mengukur derajat linier antara EPS dan DPS secara simultan (bersama-sama) terhadap harga saham, disajikan pada tabel sebagai berikut :

Tabel 4.7

Model Summary

\begin{tabular}{|l|r|r|r|r|}
\hline Model & \multicolumn{1}{|c|}{$\mathrm{R}$} & $\mathrm{R}$ Square & $\begin{array}{c}\text { Adjusted R } \\
\text { Square }\end{array}$ & $\begin{array}{c}\text { Std. Error of } \\
\text { the Estimate }\end{array}$ \\
\hline 1 &, $998^{\mathrm{a}}$ &, 996 &, 992 & 110,43530 \\
\hline
\end{tabular}

Sumber : Data diolah

Dari kolom keluaran data SPSS diatas yaitu tabel modal summary, terlihat bahwa angka $\mathrm{R}$ atau nilai koefisien korelasi berganda/ simultan adalah sebesar 0,998. Nilai ini menunjukkan bahwa hubungan terikat adalah sangat kuat. 


\section{Koefisien Korelasi Parsial}

Koefisien korelasi parsial menunjukkan hubungan antara suatu variabel dengan suatu variabel lain ketika variabel lain yang tidak dicari koefisien korelasi parsialnya dianggap konstan atau tetap. Untuk menunjukkan angkanya disajikan pada tabel dibawah ini:

\section{Tabel 4.8}

Tabel Koefisien Korelasi Parsial

Correlations

\begin{tabular}{|ll|r|r|r|}
\hline & \multicolumn{1}{|c|}{$\begin{array}{c}\text { Earning Per } \\
\text { Share }\end{array}$} & $\begin{array}{c}\text { Dividen Per } \\
\text { Share }\end{array}$ & $\begin{array}{c}\text { Harga } \\
\text { Saham }\end{array}$ \\
\hline Earning Per & Pearson & 1 &, 685 &, $897^{*}$ \\
Share & Correlation & &, 202 &, 039 \\
& Sig. (2-tailed) & 5 & 5 & 5 \\
& $\mathrm{~N}$ &, 685 & 1 &, 296 \\
Dividen Per & Pearson & & &, 629 \\
Share & Correlation &, 202 & 5 \\
& Sig. (2-tailed) &, $897^{*}$ &, 296 & 1 \\
& $\mathrm{~N}$ & & 5 & \\
Harga Saham & Pearson &, 039 &, 629 & 5 \\
& Correlation & 5 & 5 & 5 \\
& Sig. (2-tailed) & $\mathrm{N}$ & &
\end{tabular}

Sumber : Data diolah

Berdasarkan tabel 4.8 diatas, koefisien korelasi parsialnya dapat dijelaskan sebagai berikut:

a) Koefisien korelasi parsial antara EPS dengan harga saham dengan asumsi ketika variable DPS dianggap konstan. Nilai koefisien korelasi parsial antara EPS dengan harga saham yang diperoleh adalah sebesar 0,897. Hal ini menunjukkan sangat kuatnya hubungan yang terjadi antara kedua variabel, hubungan yang terjadi adalah positif atau searah, artinya bila EPS mengalami kenaikan dengan asumsi variabel DPS konstan, maka perubahan harga saham akan mengalami kenaikan pula. Begitupun sebaliknya apabila EPS mengalami penurunan dengan asumsi variabel DPS konstan, maka perubahan harga saham akan mengalami penurunan pula. Berdasarkan kriteria kekuatan hubungan variabel EPS dan harga saham ketika variabel DPS dianggap konstan adalah sangat tinggi atau sangat kuat.

b) Koefisien korelasi parsial antara DPS dengan harga saham dengan asumsi ketika variabel EPS dianggap konstan. Nilai koefisien korelasi parsial antara DPS dan harga saham yang diperoleh adalah sebesar 0,296. Hal ini menunjukkan kuatnya hubungan yang terjadi antara kedua variabel, hubungan yang terjadi adalah positif atau searah, artinya bila DPS mengalami kenaikan dengan asumsi variabel EPS konstan, maka perubahan harga saham akan mengalami kenaikan pula. Begitupun sebaliknya apabila DPS mengalami penurunan denagn asumsi variabel EPS konstan, maka perubahan harga saham akan mengalami penurunan pula. Berdasarkan kriteria kekuatan 
hubungan variabel DPS dan harga saham ketika variabel EPS dianggap konstan adalah tinggi atau kuat.

\section{Uji Signifikansi}

1. Uji Signifikansi Parsial (Uji T)

Uji T bertujuan untuk mengetahui pengaruh variabel independen yang terdiri dari EPS dan DPS terhadap harga saham pada WIKA secara parsial

Tabel 4.9

Hasil Pengujian Uji T

Coefficients $^{\mathrm{a}}$

\begin{tabular}{|c|c|c|c|c|c|}
\hline \multirow[t]{2}{*}{ Model } & \multicolumn{2}{|c|}{$\begin{array}{c}\text { Unstandardized } \\
\text { Coefficients }\end{array}$} & $\begin{array}{l}\text { Standardized } \\
\text { Coefficients }\end{array}$ & \multirow[t]{2}{*}{$\mathrm{T}$} & \multirow[t]{2}{*}{ Sig. } \\
\hline & $B$ & Std. Error & Beta & & \\
\hline (Constant) & $-239,704$ & 248,074 & &,- 966 & ,436 \\
\hline $\begin{array}{l}\text { Earning Per } \\
1 \text { Share }\end{array}$ & 60,152 & 2,806 & 1,309 & 21,435 & ,002 \\
\hline $\begin{array}{l}\text { Dividen Per } \\
\text { Share }\end{array}$ & $-137,653$ & 13,986 &,- 601 & $-9,842$ & ,010 \\
\hline
\end{tabular}

Sumber: Data diolah

Berdasarkan tabel diatas pada variabel EPS diatas diperoleh nilai $t_{\text {hitung }}$ sebesar 21,435, sedangkan $t_{\text {tabel }}$ dengan tingkat signifikansi $5 \%$ dan derajat kebebasan $(\mathrm{dk})=\mathrm{n}-\mathrm{k}-1=5-2$ $1=2$ adalah sebesar 4,303. Dengan melakukan perbandingan yaitu $t_{\text {hitung }}(21,435)>t_{\text {tabel }}$ $(4,303)$ sehingga jatuh pada daerah penolakan $H_{o}\left(H_{o}\right.$ ditolak, $H_{1}$ diterima). Serta dilihat pada table 4.9 diatas dapat dilihat pula besar angka signifikansi yaitu 0,002 yang berarti angka ini lebih kecil dari tingkat signifikansi $(0,002<0,05)$, maka dapat ditarik kesimpulan bahwa perubahan EPS secara parsial berpengaruh signifikansi terhadap perubahan harga saham.

Selanjutnya pada tabel diatas pada variable DPS diperoleh nilai $t_{\text {hitung }}$ sebesar $-9,842$, sedangkan $t_{\text {tabel }}$ dengan tingkat signifikansi $5 \%$ dan derajat kebebasan $(\mathrm{dk})=\mathrm{n}-\mathrm{k}-1=5-2$ $1=2$ adalah sebesar 4,303. Dengan melakukan perbandingan yaitu $t_{\text {hitung }}(-9,842)<t_{\text {tabel }}$ $(4,303)$ sehingga jatuh pada daerah penerimaan $H_{o}\left(H_{o}\right.$ diterima, $H_{1}$ ditolak). Serta dilihat pada tabel diatas dapat dilihat pula besar angka signifikansi sebesar 0,010 yang berarti angka ini lebih besar dari tingkat signifikansi $(0,010>0,05)$, maka dapat ditarik kesimpulan bahwa perubahan DPS secara parsial tidak berpengaruh signifikan terhadap perubahan harga saham. 


\section{Uji Signifikansi Simultan (Uji F)}

Uji $\mathrm{F}$ digunakan untuk menguji pengaruh variabel independen yaitu EPS dan DPS secara simultan atau serentak terhadap variabel dependen harga saham, yaitu dengan membandingkan antara nilai $F_{\text {hitung }}$ dengan $F_{\text {tabel }}$.

Berikut perhitungan uji hipotesis yang menggunkan uji signifikansi dengan pengujian menggunakan uji F dihitung melalui alat software program SPSS versi 20.0.

Tabel 4.10

Hasil Pengujian Uji F

ANOVA

\begin{tabular}{|c|c|c|c|c|c|c|}
\hline \multicolumn{2}{|c|}{ Model } & $\begin{array}{l}\text { Sum of } \\
\text { Squares }\end{array}$ & $d f$ & Mean Square & $\mathrm{F}$ & Sig. \\
\hline \multirow{3}{*}{1} & Regression & 6143128,089 & 2 & 3071564,044 & 251,851 & ,004 \\
\hline & Residual & 24391,911 & 2 & 12195,956 & & \\
\hline & Total & 6167520,000 & 4 & & & \\
\hline
\end{tabular}

Sumber: Data diolah

Berdasarkan hasil pengujian Analysis of Variance (ANOVA) diatas diperoleh nilai $F_{\text {hitung }}$ sebesar 251,851 dengan signifikansi 0,004 , sedangkan pada $F_{\text {tabal }}$ dengan signifikansi $5 \%$ dan $\mathrm{dfl}=\mathrm{k}=2$,df2 $=\mathrm{n}-\mathrm{k}-1=5-2-1=2$, diperoleh $F_{\text {tabel }}$ sebesar 9,55. Dengan kondisi ini dimana $F_{\text {hitung }}$ lebih besar dari pada $F_{\text {tabel }}(251,851>9,55)$ dan nilai signifikansi lebih kecil dari $\alpha=0,005(0,004<0,05)$, maka dapat diambil kesimpilan adalah $H_{o}$ ditolak dan $H_{1}$ diterima yang berarti variabel EPS dan DPS berpengaruh signifikan secara simultan terhadap harga saham.

3. Koefisien Determinasi (Adj.R.Square)

Melalui pengujian serentak dapat diketahui besarnya koefisien determinasi (Adj.R.Square). Dari koefisien determinasi (Adj.R.Square) dapat diketahui derajat ketepatan dari analisis regresi berganda menunjukkan besarnya variasi sumbangan seluruh variabel bebas terhadap variabel terikatnya.

Berdasarkan tabel "Model Summary" besarnya nilai pengaruh variabel bebas ditunjukkan oleh nilai $R^{2}=0,992$ maka (KD $=r^{2} \times 100 \%=0,992 \times 100 \%=99,2 \%$ ) jadi dapat disimpulkan bahwa EPS dan DPS berpengaruh sebesar 99,2\% terhadap Harga Saham, sedangkan 1,8\% dipengaruhi oleh variabel lain yang tidak diketahui di dalam peneliatian ini.

\section{KESIMPULAN}

Kesimpulan peneliti setelah melakukan rangkaian penelitian dari tanggal 1 Januari 2018 sampai 5 Mei 2018 tentang "Pengaruh Earning Per Share dan Dividen Per Share Terhadap Harga Saham" dapat dibuat beberapa simpulan dari tujuan penelitian ini.

1. Pengaruh Earning per Share (EPS) terhadap harga saham WIKA 2010-2014. Berdasarkan hasil perhitungan EPS pada WIKA yang dijelaskan bahwa EPS WIKA selalu meningkat tiap tahunnya, dimulai dari tahun 2010 sampai dengan tahun 
2014 tetapi pada tahun 2015 mengalami penurunan. Berdasarkan data diatas EPS tertinggi WIKA terjadi pada tahun 2014 yaitu sebesar 119.71 dan tahun terendah WIKA terjadi pada tahun 2010 yaitu sebesar 51.86. Laba bersih WIKA yang terus meningkat dimulai dari tahun 2010 sebesar 311.241 .250 naik menjadi 401.827.929 pada tahun 2011, dengan jumlah saham yang beredar pada tahun 2010 sebesar 6.001.540 dan naik pada tahun 2011 sebesar 6.027.267 sehingga mengakibatkan kenaikan pada EPS dari 51.86 pada tahun 2010 menjadi 66.66 pada tahun 2011 . Begitupun selanjutnya setiap tahunnya laba serta jumlah saham beredar terus meningkat sehingga EPS pun meningkat sampai dengan tahun 2014.

2. Pengaruh Dividend per Share (DPS) terhadap harga saham WIKA 2010-2014. Nilai DPS pada tahun 2010-2014 mengalami peningkatan, dimulai pada tahun 2010 sebesar 15.55, tahun 2011 sebesar 23.33, tahun 2012 sebesar 25.88, dan pada tahun 2013 sebesar 30.50. Tetapi pada tahun 2014 WIKA mengalami penurunan sebesar 23.94.

3. Pengaruh EPS dan DPS secara simultan terhadap harga saham WIKA 2010-2014. Meningkatnya harga saham tahun 2012 sebesar 143\% merupakan dampak dari meningkatnya EPS di tahun 2006. Harga saham WIKA yang meningkat paling besar sebesar $143 \%$ pada tahun 2012, merupakan pemulihan dari krisis ekonomi dunia serta juga investor melihat grafik WIKA meningkat yang tidak mengalami dampak dari krisis ekonomi dunia. Peningkatan harga saham 2013 sebesar 3\% walaupun tidak terlalu besar ini membuktikan adanya kenaikan yang dipengaruhi oleh EPS serta kenaikan kembali yang signifikan di tahun 2014 sebesar 133\% yang disebabkan oleh kenaikan nilai laba bersih serta EPS yang meningkat.

\section{DAFTAR PUSTAKA}

Harjito dan Martono, (2005), “Manajemen Keuangan”, Ekonisia, Yogyakarta, 2005.

Imam Ghozali, (2015), "Aplikasi Analisis Multivariate dengan Program SPSS", Edisi Kelima, Badan Penerbit Undip, Semarang.

Kasmir, (2012) "Pengantar Manajemen Keuangan", Edisi Pertama, Cetakan kedua, Penerbit Prenada Media, Jakarta.

Martono dan Agus Harjito, (2011), "Manajemen Keuangan", Penerbit Ekonisia, Yogyakarta.

Munawir, 2009 "Analisa Laporan Keuangan”, Cetakan keempat, Penerbit Liberty, Yogyakarta. Riyanto dan Bambang, 2008, "Dasar-Dasar Pembelanjaan Perusahaan”, BPFE, Yogyakarta.

Robbins, S. P., Marry, C., Neharika, V., 2012,"Management” Edisi Kesepuluh, New Jersey: Prentice Hall.

Sartono, (2010), "Manajemen Keuangan Toeri dan Aplikasi”, Edisi keempat, Penerbit BPFEYogyakarta.

Sofyan Syafri Harahap, (2009), “Analisis Kritis Atas Laporan Keuangan”, RajaGrafindo Persada, Jakarta.

Sugiyono, 2014, "Metode Penelitian Kuantitatif Kualitatif dan R \& D", Penerbit CV. Alfabeta, Bandung.

Sutrisno, (2009), “Manajemen Keuangan Teori, Konsep dan Aplikasi”, Penerbit Ekonisia, Yogyakarta. 